\title{
Pengaruh Lama Pengukusan terhadap Suhu Gelatinisasi, Retensi Bahan Kering dan Energi Metabolis Tepung Ubi Jalar (Ipomoea batatas L.) pada Ayam Broiler
}

\author{
Deny Saefulhadjar ${ }^{1, a}$, Denny Rusmana ${ }^{1}$, Hendi Setiyatwan ${ }^{1}$, Ana Rochana Tarmidi ${ }^{1}$ \\ ${ }^{1}$ Departemen Nutrisi Ternak dan Teknologi Pakan, Fakultas Peternakan, Universitas Padjadjaran \\ a email: deny.saefulhadjar@unpad.ac.id
}

\begin{abstract}
Abstrak
Penelitian untuk mengetahui suhu gelatinisasi dan retensi tepung ubi jalar (Ipomoea batatas L.) pada ayam broiler akibat pengukusan dilaksanakan di Laboratorium Nutrisi Ternak Unggas Non Ruminansia dan Industri Makanan Ternak Universitas Padjadjaran Jatinangor. Ubi jalar diberi empat perlakuan, yaitu tanpa pengukusan, dan pengukusan selama 15, 30, dan 45 menit. Suhu gelatinisasi tepung umbi ubi jalar diukur menggunakan Pertens Rapid Visco Analizer. Pengukuran retensi bahan kering dan energi metabolis ransum dilakukan dengan metode koleksi total feses. Ayam pedaging strain Cobb sebanyak 20 ekor yang berumur 5 minggu ditempatkan pada 20 kandang individu yang terbuat dari kawat dengan ukuran 55 × 35 x $60 \mathrm{~cm}$. Rancangan yang digunakan adalah rancangan acak lengkap (RAL). Hasil pengukuran menunjukkan bahwa suhu gelatinisasi ubi yang dikukus nyata berbeda $(\mathrm{P}<0,05)$ dengan ubi yang tidak dikukus. Suhu gelatinisasi antar lama pengukusan berbeda tapi tidak nyata $(\mathrm{P}>0,05)$. Retensi bahan kering, energi metabolis $(\mathrm{EM})$, dan energi metabolis terkoreksi nitrogen $(\mathrm{EMn})$ pada pengukusan selama 15 menit semuanya nyata lebih tinggi $(\mathrm{P}<0,05)$ dari ubi jalar yang tidak dikukus, namun tidak berbeda nyata $(\mathrm{P}>0,05)$ dari ubi jalar yang dikukus. Pengukusan selama 15 menit cukup untuk meningkatkan retensi ubi jalar.
\end{abstract}

Kata kunci : Ubi jalar, suhu gelatinisasi, retensi bahan kering, energi metabolis, ayam broiler

\section{The Effect of Steaming on Sweet Potato (Ipomoea batatas L.) Meal Gelatinization Temperature, Dry Matter Retention and Metabolizable Energy on Broiler Chicken}

\begin{abstract}
A research aimed to know the sweet potato (Ipomoea batatas L.) gelatinization temperature, dry matter retention and metabolizable energy on broiler chicken was carried out at the Poultry NonRuminant Nutrition and Feed Industry Laboratory of Universitas Padjadjaran, Jatinangor. There were four treatments, without steaming, and steaming for 15, 30, and 45 minutes. The gelatinization termperature properties of sweet potato flour were measured using Pertens Rapid Visco Analizer. Measurements of dry mater (DM) retention and metabolic energy (ME) of the diet were carried out by total feces collection. 20 Cobb broiler strains aged 5 weeks were placed in 20 individual cages made of wire with a size of $55 \times 35 \times 60 \mathrm{~cm}$. The design used is a completely randomized design (CRD). The measurement results showed that the properties of steamed $S P$ were statistically different $(P<0.05)$ from those of non-steamed $S P$, indicating the presence of gelatinization of starch in steamed $S P$, but there was no significant difference among them. DM retention, $M E$, and nitrogen-corrected $M E$ at steaming for 15 minutes were all significantly higher $(P<0.05)$ than un-steamed $S P$, but not significantly $(P>0.05)$ among steamed sweet potatoes. Steaming for 15 minutes is enough to increase sweet potato retention.
\end{abstract}

Keywords: Sweet potato, gelatinization temperature, dry matter retention, metabolizable energy, broiler chicken 


\section{Pendahuluan}

Umbi ubi jalar (Ipomoea batatas L.) potensial digunakan sebagai sumber energi dalam ransum unggas. Bahan kering ubi jalar mengandung 75-90 persen karbohidrat (Koswara, 2009). Kandungan energi metabolis tepung ubi jalar untuk ayam hampir menyamai tepung jagung, yaitu 3200 kkal/kg (Machin, 1992; Aina dan Fanimo, 1997). Kandungan karotenoid pada ubi jalar berdaging oranye dapat mencapai $200 \mu \mathrm{g} / \mathrm{g}$ (Jaswir dkk., 2011), melebihi kandungannya pada jagung kuning. Pati adalah sumber utama energi dari ubi jalar, sekaligus potensial sebagai perekat pelet. Pati pada ubi jalar segar sebanyak 46,2 persen dari bahan keringnya (Koswara, 2009).

Pati ubi jalar mentah lebih resisten terhadap aksi enzim percernaan seperti alfaamilase daripada pati biji-bijian (Woolve, 1992). Enzim akan mudah mencerna saat granula pati pecah (tergelatinisasi) akibat proses pemasakan. Pemasakan mengakibatkan perubahan sebanyak 42-95 persen pada pati ubi jalar, menjadi maltosa (72-99 persen) dan sisanya dekstrin (Koswara 2009). Pengukusan mengakibatkan pati ubi jalar tergelatinisasi (Syamsir dan Honestin, 2009). Gelatinisasi pada pati dapat terjadi sebagian atau keseluruhan bergantung pada ketersediaan air dan tingkat panas yang diberikan serta lamanya proses pemasakan pada bahan (Kitahara, 2005; Bastian, 2011). Pati yang tergelatinisasi mempunyai kemampuan menyerap air lebih besar dan kecernaannya lebih baik dibandingkan pati mentah (Yoshida, et al., 1962; Syamsir dan Honestin, 2009; Svihus, 2014).

Proses pemasakan dan perlakuan panas yang berbeda terhadap bahan pakan sumber pati memberikan pengaruh tingkat gelatinisasi yang berbeda. Gelatinisasi pada pati dapat terjadi sebagian atau keseluruhan bergantung pada ketersediaan air dan tingkat panas yang diberikan serta lamanya proses pemasakan pada bahan (Kitahara dkk., 2005; Bastian, 2011). Pati jagung yang diproses steam flaking tergelatinisasi sebanyak 21,33 persen, 25,47 persen dalam proses pemeletan, 63,58 persen dalam proses micronization, dan 100 persen tergelatinisasi dalam proses ekstrusi (Kokic dkk., 2013).

Pengukusan adalah proses pemasakan basah menggunakan panas dari uap air yang mendidih $\left(100^{\circ} \mathrm{C}\right)$. Lama pengukusan menentukan tingkat perubahan yang terjadi dari bahan yang dimasak. Pada awal proses pengukusan, pati akan mengalami pembengkakan karena air memasuki granula dan terus bertambah hingga dalam waktu tertentu granula akan pecah atau tergelatinisasi sempurna. Pati yang tergelatinisasi akan lebih tinggi tingkat kecernaan dan retensinya dibanding pati mentah. Tingkat gelatinisasi pati akibat lama pegukusan yang berbeda dapat diketahui antara lain dengan pengujian sifat pasta menggunakan Rapid Visco Analyzer (RVA) atau Brabender Visco-amilograph. Pada pati yang tergelatinisasi, suhu awal pasta pada saat pemanasan dalam uji lebih rendah dibanding pada pati mentah, dan juga tidak mempunyai nilai viskositas maksimum karena granula telah pecah (Syamsir dan Honestin, 2009). Retensi bahan kering dan energi metabolis pada ayam broiler adalah dua parameter yang bisa menunjukkan nilai kecernaan suatu bahan sebelum dan setelah dimasak. Pati yang berjumlah dominan pada bahan dibedakan kecernaannya pada status pemasakan.

\section{Metode Penelitian \\ Ubi Jalar dan Prosedur Pengukusan}

Ubi jalar mentah, diperoleh dari pedagang pengumpul di Desa Sindangsari Kecamatan Sukasari Kabupaten Sumedang. Umbi yang digunakan merupakan umbi utuh berukuran kecil yang merupakan hasil sortiran ubi varietas Cilembu untuk konsumsi, berdiameter melintang antara 2 hingga 4 centimeter. Alat yang digunakan antara lain panci pengukus, kompor gas, stop watch, termometer, hammer mill, rapid visco analyzer, dan perangkat alat analisis proksimat.Ubi utuh dibersihkan dan dimasukkan ke dalam panci pengukus dengan air yang sudah mendidih, suhu $100^{\circ} \mathrm{C}$, dicatat waktu saat ubi masuk. Ubi kukus dikeluarkan sesuai waktu perlakuan, yaitu 15,30 , dan 45 menit. Ubi kukus diangin-anginkan, diiris-iris dan dijemur hingga kering. Ubi kukus kering selanjutnya 
digiling menjadi tepung menggunakan hammer mill dengan saringan berdiameter 3 $\mathrm{mm}$.

\section{Suhu Gelatinisasi Tepung}

Suhu gelatinisasi tepung ubi jalar kukus (TUJK) yang menunjukkan perubahan suhu awal gelatinisasi akibat perbedaan lama pengukusan, diuji menggunakan Perten RVA StarchMaster 2. Sampel dihancurkan menggunakan blender hingga menjadi tepung. Tepung ditimbang sebanyak $3 \mathrm{~g}$, kemudian ditambahkan air sebanyak $25 \mathrm{~g}$ dan dipanaskan di dalam tabung aluminium yang dilengkapi dengan kayuh (impeller) plastik. Sampel diperlakukan sesuai program suhu dan waktu yang telah diatur, yakni pemanasan, sampai diperoleh viskositas puncak, penahanan selama lima menit, dan pendinginan. Sifat pasta dari sampel yang diuji diperoleh berupa file yang bisa dibaca dan dicetak melalui komputer.

\section{Retensi Bahan Kering, Nitrogen dan Energi Metabolis}

Pengujian retensi bahan kering, protein dan energi metabolis menggunakan ayam pedaging strain Cobb sebanyak 20 ekor berumur 5 minggu. Semua ayam ditempatkan pada 20 kandang individu yang terbuat dari kawat dengan ukuran $55 \times 35 \mathrm{x}$ $60 \mathrm{~cm}$. Makanan dan air minum diberikan secara ad libitum. Peralatan yang digunakan adalah tempat pakan, tempat minum, lampu pijar, timbangan, tempat menampung ekskreta, kantong plastik, oven pengering dan alat penggiling sampel.

Ayam dipuasakan dahulu selama 24 jam, kemudian diberi tepung ubi jalar perlakuan sebanyak 70 gram per ekor per hari, lalu dilakukan koleksi total ekskreta dalam 3 hari berturut-turut. Bersamaan dengan pengumpulan ekskreta dilakukan pencatatan konsumsi ransum, konsumsi air minum, bobot ekskreta per hari. Penampungan ekskreta dalam wadah yang berlapis plastik di bawah kandang. Ekskreta yang terkumpul dibersihkan dari rontokan bulu dan kotoran, kemudian kepada seluruh sampel eksreta yang terkumpul, ditambahkan $5 \quad \mathrm{ml} \quad \mathrm{H}_{2} \mathrm{SO}_{4} \quad 0,3 \mathrm{~N}$ untuk mengikat nitrogen. Selanjutnya ekskreta dikeringkan di dalam oven dengan suhu $60^{\circ} \mathrm{C}$ selama 24 jam. Ekskreta kering ditimbang dan dianalisis kadar air, protein kasar dan energi bruto. Peubah yang diukur meliputi retensi bahan kering, nitrogen dan energi metabolis dengan rumus sebagai berikut:

\section{$R B K=K P \times B K P-B E \times B K E$}

Keterangan :

RBK = Retensi bahan kering (g/ekor/hari)

$\mathrm{KP}=$ Konsumsi Pakan $(\mathrm{g})$

NP $=$ Bahan kering Pakan

$\mathrm{BE}=$ Bobot Ekskreta

$\mathrm{NE}=$ Bahan kering Ekskreta

$R N=K P \times N P-B E x N E$

Keterangan:

$\mathrm{RN}=$ Retensi Nitrogen (g/ekor/hari)

$\mathrm{KP}=$ Konsumsi Pakan

NP $=$ Nitrogen Pakan

$\mathrm{BE}=$ Bobot Ekskreta

$\mathrm{NE}=$ Nitrogen Ekskreta

$E M=K P \times E B P-B E \times E B E$

Keterangan:

$\mathrm{EM}=$ Energi metabolis $(\mathrm{Kkal} / \mathrm{kg})$

$\mathrm{KP}=$ Konsumsi Pakan

$\mathrm{EBP}=$ Energi bruto pakan

$\mathrm{BE}=$ Bobot ekskreta

$\mathrm{EBE}=$ Energi bruto ekskreta

Data yang diperoleh dari retensi energi bahan kering, energi metabolis dan protein diolah menggunakan analisis varian dilanjutkan dengan Uji Duncan, untuk menentukan lama pengukusan yang menunjukkan tingkat retensi produk hasil kukusan pada ayam.

\section{Hasil dan Pembahasan}

Suhu awal gelatinisasi dan suhu pecahnya granula pati tepung ubi jalar hasil pengujian menggunakan Rapid Visco Analyzer (RVA) ditampilkan pada tabel 1. 
Tabel 1. Suhu Awal Gelatinisasi dan Suhu Granula Pati Pecah Tepung Ubi Jalar pada Berbagai Tingkat Lama Pengukusan

\begin{tabular}{lll}
\hline $\begin{array}{l}\text { Lama Pengukusan } \\
\text { (menit) }\end{array}$ & $\begin{array}{l}\text { Suhu } \\
\text { Gelatinisasi } \\
\left({ }^{\circ} \mathrm{C}\right)\end{array}$ & $\begin{array}{l}\text { Awal } \\
\text { Suhu Granula Pati } \\
\text { Pecah } \\
\left({ }^{\circ} \mathrm{C}\right)\end{array}$ \\
\hline 0 & 76,27 & 85,15 \\
15 & 53,21 & - a) \\
30 & 70,54 & $-\quad$ a) \\
45 & 51,17 & $-\quad$ a) \\
\hline
\end{tabular}

a) Granula pati telah pecah pada proses pengukusan

Hasil pengujian tepung ubi jalar menggunakan Rapid Visco Analyzer menunjukkan adanya perbedaan antara tepung ubi jalar yang dikukus dengan yang tidak dikukus. Suhu awal gelatinisasi tampak menurun dari $76,27^{\circ} \mathrm{C}$ pada TUJ yang tidak dikukus menjadi 53,21 dan 51,17 pada TUJ yang dikukus pada masing-masing selama 15 dan 45 menit. Sedikit penurunan terjadi pada pengukusan selama 30 menit. Penurunan ini sejalan dengan Syamsir \& Honestin (2009), bahwa suhu awal gelatinisasi TUJ mentah adalah sekitar $77^{\circ} \mathrm{C}$, sedangkan pada TUJ proses sawut-kukuspengeringan oven adalah $30,9^{\circ} \mathrm{C}$ dan pada hasil proses sawut-kukus-pengeringan jemur adalah $56,5^{\circ} \mathrm{C}$. Suhu awal gelatinisasi pati ubi jalar Jepang varietas biasa (Koganesengan) mentah adalah $73,6^{\circ} \mathrm{C}$ (Kitahara, dkk., 2005) dan pada pati ubi jalar komersil mentah $87,81^{\circ} \mathrm{C}$ (Li, dkk., 2014).

Suhu awal gelatinisasi pada TUJ yang dikukus menjadi lebih rendah dari sebelumnya saat mentah, karena pada proses pengukusan sudah terjadi gelatinisasi pada patinya (Syamsir dan Honestin, 2009). Saat TUJ dipanaskan kembali dalam pengujian sifat pasta menggunakan Rapid Visco
Analyzer, suhu gelatinisasinya sudah lebih rendah dari sebelum dikukus (mentah).

\section{Retensi Bahan Kering, Nitrogen dan Energi Metabolis}

Pengaruh perlakuan lama pengukusan terhadap retensi bahan kering ubi jalar disajikan pada Tabel 2. Kisaran retensi bahan kering pada semua perlakuan adalah antara 20,62-73,04 persen/ekor/hari.

Retensi BK perlakuan berkisar antara 25,15 hingga 47,24 persen/ekor/hari, masing-masing untuk ubi jalar yang tidak dikukus dan ubi jalar yang dikukus selama 15 menit. Pada ubi jalar yang dikukus selama 30 dan 45 menit, nilai retensi BK-nya adalah 44,01 dan 44,42 persen/ekor/hari. Nilai retensi BK ini jauh lebih kecil dari yang dilaporkan oleh Bryant \& Anderson (2017), yaitu $88 \%$, untuk ubi jalar yang direbus selama 30 menit. TUJ yang digunakan dalam penelitian ini berasal dari ubi jalar berukuran kecil (diameter 2-5 cm), digunakan seluruh bagiannya tanpa pengupasan. Bagian kulit yang sulit dicerna memberi kontribusi pada rendahnya retensi bahan kering.

Tabel 2. Rataan Retensi Bahan Kering, Energi Metabolis dan EMn

\begin{tabular}{|c|c|c|c|c|}
\hline \multirow{2}{*}{ Peubah } & \multicolumn{4}{|c|}{ Lama Pengukusan (Menit) } \\
\hline & 0 & 15 & 30 & 45 \\
\hline $\begin{array}{l}\text { Retensi BK UJK } \\
\text { (persen/ekor/hari) }\end{array}$ & $25,15^{\mathrm{b}}$ & $47,24^{\mathrm{a}}$ & $44,01^{\mathrm{a}}$ & $44,42^{\mathrm{a}}$ \\
\hline $\begin{array}{l}\text { Retensi } \quad \text { EM } \\
\text { (kkal/kg/ekor/hari( }\end{array}$ & $856^{\mathrm{b}}$ & $1499^{\mathrm{a}}$ & $1324^{\mathrm{ab}}$ & $1322^{\mathrm{ab}}$ \\
\hline $\begin{array}{l}\text { Retensi } \quad \text { EMn } \\
\text { (kkal/kg/ekor/hari) }\end{array}$ & $770^{\mathrm{b}}$ & $1349^{\mathrm{a}}$ & $1192^{\mathrm{ab}}$ & $1190^{\mathrm{ab}}$ \\
\hline
\end{tabular}

Ket. : Huruf superscript yang berbeda ke arah baris menunjukkan berbeda nyata $(\mathrm{P}<0,05)$ 
Perlakuan pengukusan terhadap ubi jalar memberikan pengaruh yang nyata $(\mathrm{P}<0,05)$ terhadap retensi bahan kering (RBK) tepung ubi jalar. Uji Duncan menunjukkan bahwa semua tepung ubi jalar yang dikukus $(15,30$, 45 menit) nyata lebih tinggi persentase RBK-nya $(\mathrm{P}<0,05)$ tehadap tepung ubi jalar mentah. Tidak ada perbedaan RBK di antara tepung ubi jalar yang dikukus $(15,30,45$ menit).

Retensi EM dan EMn ubi jalar mentah adalah 856 dan $770 \mathrm{kkal} / \mathrm{kg}$, keduanya nyata $(\mathrm{P}<0,05)$ lebih rendah daripada EM dan EMn ubi jalar kukus selama 15 menit (UJK 15, masing-masing 1499 dan $1349 \mathrm{kkal} / \mathrm{kg}$ ). Retensi EM dan EMn ini sesuai dengan hasil penelitian Bryant dan Anderson (2017) yang menunjukkan hasil berbeda nyata antara ubi jalar mentah dan ubi jalar masak (rebus).

Peningkatan retensi BK, EM dan EMn setelah ubi jalar dikukus adalah akibat dari peningkatan kecernaan ubi jalar setelah patinya mengalami gelatinisasi (Woolfe, 1992; Syamsir dan Honestin, 2009; Richana dan Widaningrum, 2009; Setiawan, 2010). Gelatinisasi pati umumnya meningkatkan akses enzimatik terhadap rantai glukosida untuk mencerna (Moritz, dkk., 2005; Beyer, dkk., 2006).

\section{Kesimpulan}

Lama pengukusan selama 15 menit pada ubi jalar mentah telah menurunkan suhu awal gelatinisasi dari $76,27^{\circ} \mathrm{C}$ menjadi $53,21^{\circ} \mathrm{C}$, dan meningkatkan retensi bahan kering (BK) dari 25,15\% menjadi 47,24\%, meningkatkan retensi energi metabolis (EM) dari 856 menjadi $1477 \mathrm{kkal} / \mathrm{kg} / \mathrm{ekor} /$ hari dan meningkatkan energi metabolis terkoreksi $\mathrm{N}$ $\begin{array}{llll}\text { (EMn) dari } 770 \quad \text { menjadi } & 1349\end{array}$ $\mathrm{kkal} / \mathrm{kg} / \mathrm{ekor} / \mathrm{hari}$.

\section{Daftar Pustaka}

Beyer, R.S. 2006. Feed manufacturing effects on poultry feed quality and nutrition. In ASA Technical Report Series: Poultry Nutrition and Management. ASA International Marketing Southeast Asia. Singapore. 5-10.

Bryan, D.D.S.L. \& Anderson, D.M. 2017. Apparent metabolizable energy of sweet potato by-products for broiler chickens. International Journal of
Agriculture, Environment and Bioresearch 2 (5), 183-191.

Fetuga, B. L. \& Oluyemi, J. A. 1976. The metabolizable energy of some tropical tuber meals for chicks. Poultry Science 55 (3) 1, 868-873.

Kitahara, K., Fukunaga, S., Katayama, K., Takahata, Y., Nakazawa, Y., Yoshinaga, M. \& Suganuma, T. 2005. Physicochemical properties of sweetpotato starches with different gelatinization temperatures. Starch 57, 473-479.

Li, G., Liu, B., Zhang, G., Zeng, J., Sun, J. \& Ma, H. 2014. Characterization of digestion resistance sweet potato starch phosphodiester. Tropical Journal of Pharmaceutical Research 13 (9), 13931400.

Moritz, J. S., Parsons, A. S., Buchanan, N. P., Calvalcanti, W. B., Cramer, K. R. \& Beyer, R. S.. 2005. Effect of gelatinizing dietary starch through feed processing on zero to three-week broiler performance and metabolism. $J$. Appl. Poult. Res. 14, 47-54.

Ravindran, V. \& Sivakanesan, R. 1996. Replacement of maize with sweet potato (Ipomoea batatas) tuber meal in broiler diets. Br. Poult. Sci., 37, 95-103.

Richana, N \& Widaningrum. 2009. Penggunaan tepung dan pasta dari beberapa varietas ubijalar sebagai bahan baku mi. J.Pascapanen 6 (1), 4353

Setiawan, S. 2010. Improving feed quality by proper processing of raw materials. Iowa State University Graduate Theses and Dissertations. Paper 11444. 47-48.

Syamsir, E. \& Honestin, T. 2009. Karakteristik fisiko-kimia tepung ubi jalar (Ipomoea batatas) varietas sukuh dengan variasi proses penepungan. J.Teknol. dan Industri Pangan, Vol. XX No. 2. 91-96.

Woolfe, J.A. 1992. Sweet potato: An untapped food resource. Cambridge University Press. 46-47.

Yoshida, M., Hoshii, H. \& Morimoto, H. 1962. Nutritive value of sweet potato as carbohydrate source in poultry feed. Agricultural and Biological Chemistry, 26:10, 679-688 